\title{
Plant health: How diagnostic networks and interagency partnerships protect plant systems from pests and pathogens
}

by Richard M. Bostock, Carla S. Thomas, Richard W. Hoenisch, Deborah A. Golino and Georgios Vidalakis

\begin{abstract}
Early detection and rapid response are crucial in any effort to reduce the risk of new and emerging biological threats to crops and other plant resources. This underscores the importance of having the necessary diagnostic expertise, infrastructure and resources in place. Three programs - the National Plant Diagnostic Network, the National Clean Plant Network and the Citrus Clonal Protection Program - illustrate how accurate and rapid diagnosis plays a critical role in providing healthy plants for growers and in securing production systems for food and fiber. These three programs depend on statewide, regional and national networking among university, state and federal scientists, regulatory officials and industry members to help mitigate the impacts of plant pests and diseases.
\end{abstract}

$\mathrm{P}$ lant pathogens and pests present continual challenges to the production and security of food, fiber and forest resources. Introduced biological agents threaten crops and forests locally and regionally with their direct damage to host plants, and their presence has national and international consequences for trade and regulatory policy. Contaminated seed and nursery plants provide efficient introduction pathways for pests, highlighting the critical importance of clean seed and nursery programs for protection of both domestic and export markets. Introduced biological agents, whether they arrive via natural dispersal mechanisms or through human activity, may remain present but below our threshold for detection and perception for years, only to emerge later with seeming suddenness and dramatic destructive intensity (Crooks 2005).

As is the case in human and animal medicine, early detection, accurate diagnosis and rapid response are critical for achievement of successful outcomes when dealing with outbreaks of endemic and newly introduced plant diseases and insect or weed pests. The United States has a long history of pathogen and pest

Online: http://californiaagriculture.ucanr.edu/ landingpage.cfm?article=ca.v068n04p117\&fulltext=yes doi: 10.3733/ca.v068n04p117 introductions for which containment and eradication have been unsuccessful, often with devastating consequences to agriculture and natural ecosystems (Pimentel et al. 2005; Rossman 2009). In California, the past two decades have seen the emergence of a number of high-consequence plant pests, including the sudden oak death pathogen, the Pierce's disease pathogen (carried by the glassy-winged sharpshooter) and more recently the Asian citrus psyllid, vector of the citrus greening disease (huanglongbing), and the European grapevine moth. California is the leading U.S. state for agricultural products, with gross cash receipts in 2011 in excess of $\$ 43$ billion (CDFA 2013) for more than 400 commodities, including numerous specialty crops. In fact, seven of the top 10 commodities in terms of cash value in California are specialty crops. All of this presents great opportunities, as well as risks and challenges, for diagnostic, pest management and clean stock and seed programs.

During the past decade, awareness and concern have increased in regard to the threat of economic harm to U.S. crop agriculture, nurseries and forests posed by introduced biological agents, and society has responded with greater investments in biosecurity programs to enhance surveillance and detection. Understandably, exotic and high-consequence agents receive the greatest focus in such programs, but it is important to note that sufficient diagnostic infrastructure and expertise must be continually maintained so we can accurately identify both routine and unusual conditions.

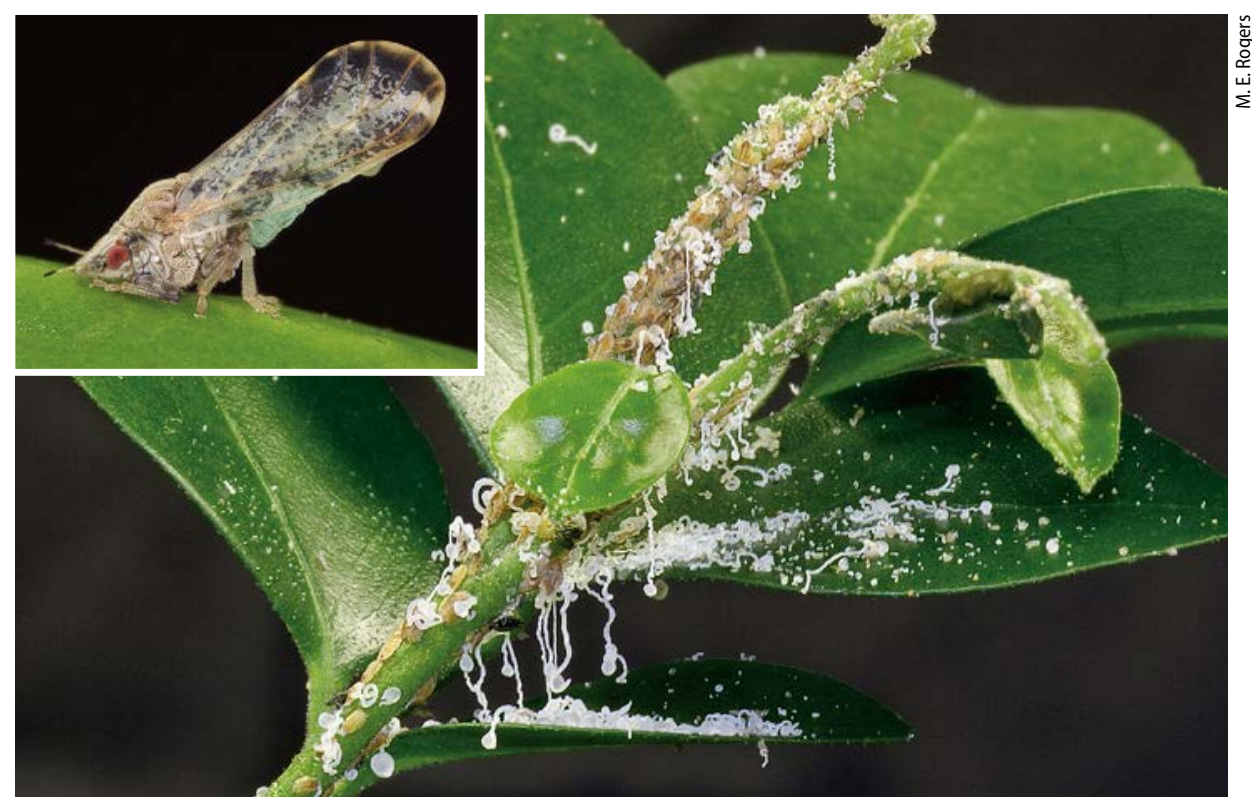

Heavy infestation of Asian citrus psyllids (Diaphorina citri) on Murraya. Inset, adult psyllid. 
Even with recent investments in plant biosecurity programs, the immensity of the task exceeds the resources currently available to adequately address it. For example, the most significant pathway for introduction of unwanted plant pathogens and pests is through live plant imports, which have increased, on average, by 51 million plants per year for the past 43 years (Liebhold et al. 2012; Palm and Rossman 2003). In 2010, more than 2.8 billion plants intended for planting within the United States passed through federal plant inspection stations at U.S. ports of entry. This sheer volume of plants by itself reduces the likelihood that all of the potentially invasive pests and pathogens will be intercepted, and that in turn makes downstream programs for detection, diagnosis and containment all the more important.

\section{The National Plant Diagnostic Network}

The National Plant Diagnostic Network (NPDN) was established in 2002 to provide greater support for and integration of plant diagnostic laboratories in the United States and help thwart the establishment and dispersal of introduced insect and weed pests and pathogens (npdn.org/). The NPDN works with state and federal agencies to ensure the quick, accurate and secure conveyance of information and expertise about new detections in order to minimize their economic and ecological impacts (Stack et al. 2006; Stack et al. 2014).

Federal funding for the establishment of the NPDN and a parallel program for animal agriculture, the National Animal Health Laboratory Network (NAHLN), was largely a response to biosecurity risks to plant and animal agriculture in the United States. Also compelling for decision-makers at the time was a growing awareness that many publicly funded plant diagnostic labs associated with land-grant universities (LGUs) and state departments of agriculture were in fact underfunded and were, in some cases, at risk of closure as a result. In addition, it appeared that a lack of coordination among diagnosticians and experts at university, state and federal laboratories could create bottlenecks in the processing of critical samples and delays in communication of diagnostic results.

The NPDN is supported in part by the USDA's Food and Agriculture Defense Initiative (FADI), a program within the National Institute of Food and Agriculture (NIFA). To further its core missions of diagnostics, training and education, and communication, the NPDN provides resources for diagnostic laboratory infrastructure and supplies, delivers advanced training for diagnosticians and educational programs for "first detectors," facilitates communication among plant diagnosticians at LGUs, state departments of agriculture and national expert laboratories, and seeks to provide accurate and timely information to state and federal authorities to guide an appropriate response. For greater efficiency in program delivery, the NPDN is divided into five geographic regions, each with a regional center located in the plant pathology department of an LGU (fig. 1), where its directors help identify and coordinate local and regional scientific expertise in plant pathology, entomology and weed/ plant science as needed. The NPDN does not have any formal regulatory authority of its own; rather, the network's principal role is to provide a framework that facilitates access to additional expertise in the event of a plant health emergency.

Given the agricultural diversity of the United States, the regionally distributed structure of the NPDN enables each region to tailor the resources and programs it provides to best meet the needs of that particular region. For example, the Western region includes 10 Western states and U.S. Pacific territories that partner to form the Western Plant Diagnostic Network (WPDN; wpdn.org/). The regional center, located at UC Davis,

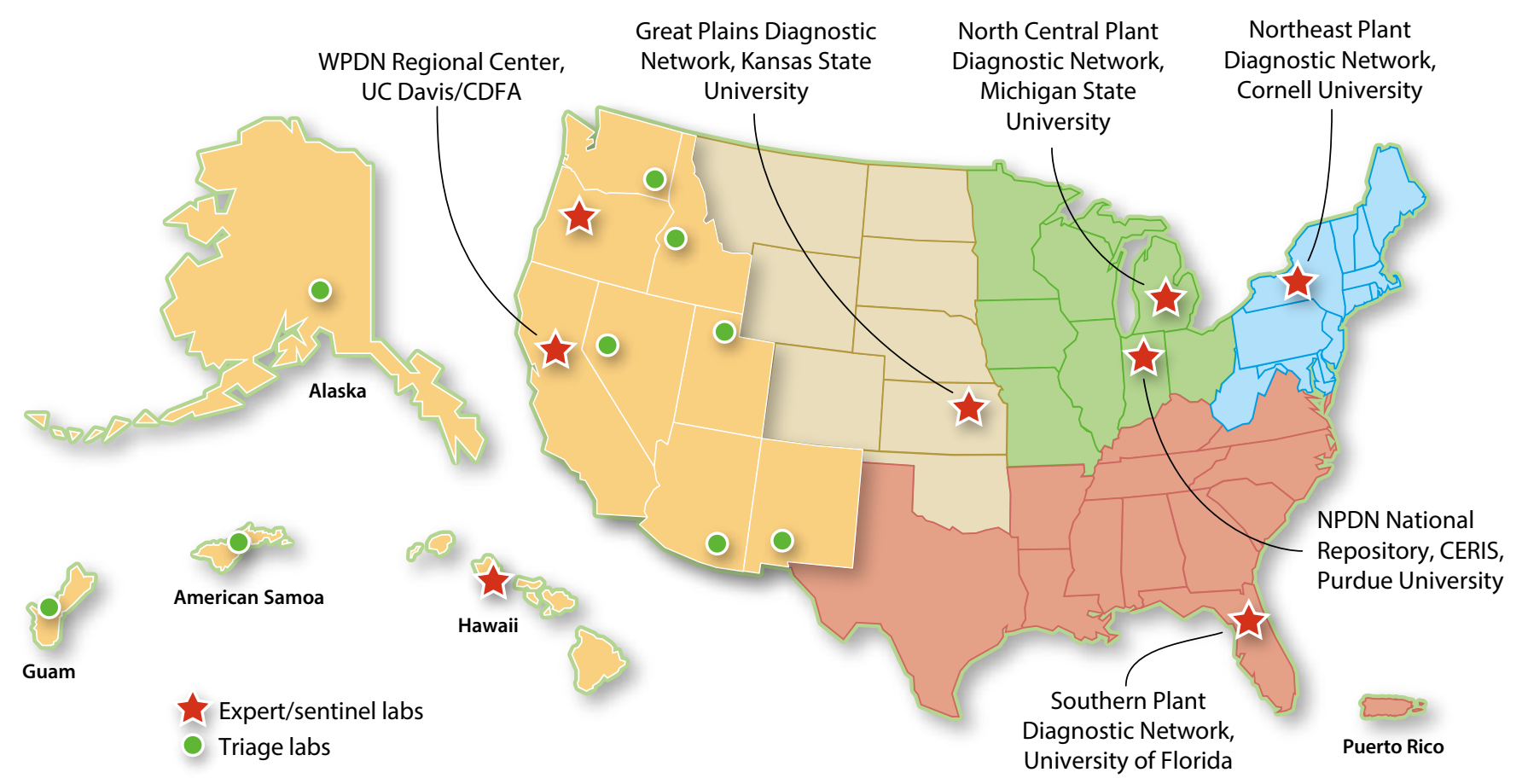

Fig. 1. Organizational map of the National Plant Diagnostic Network with the five regional networks and the NPDN National Repository at Purdue University. The Western Plant Diagnostic Network (WPDN) includes 10 Western states and U.S. territories in the Pacific. 
works in partnership with the California Department of Food and Agriculture (CDFA) Plant Pest Diagnostic Center, which is the formal diagnostic reporting authority for California (cdfa.ca.gov/ plant/PPD/).

The scope and size of agricultural, nursery and forest production systems, as well as infrastructure and expertise in support of plant health programs, vary considerably throughout the WPDN, with three subregional expert laboratories that work together with the various triage laboratories in individual states and territories. The three expert laboratories the CDFA laboratory in Sacramento and diagnostic laboratories at Oregon State University (Corvallis) and the University of Hawaii (Manoa), working in partnership with the Hawaii Department of Agriculture - can handle most or all types of samples and conduct collaborative diagnostics with other member laboratories in the region or the nation. The CDFA laboratory is the largest and most comprehensive state plant diagnostic laboratory in the United States, with more than 70 scientists and support staff specializing in pests, diseases, weeds, nematodes and seed certification. It receives little funding from the NPDN, relative to the scope and size of the laboratory's activities, drawing its primary support from state funds and other grants.

Similar to the WPDN, the other four regional networks in the NPDN are consortia of LGUs and state departments of agriculture working together to support mission-related activities and provide diagnostic services. Diagnostic results from NPDN member laboratories in all 50 states and three U.S. territories are submitted to the NPDN National Repository at Purdue University's Center for Environmental and Regulatory Information Systems (CERIS; ceris. purdue.edu/npdn/). At the time of this writing (September 2014), the repository houses more than 930,000 diagnostic sample records in a database that is updated daily; it receives about 100,000 new records each year from as many as 150 laboratories throughout the nation. Such a comprehensive national database of diagnostic records is unprecedented in plant agriculture. It is available for search and analysis by authorized scientists, regulatory officials and diagnosticians who use it to rapidly identify novel detections and discern patterns of new outbreaks at various scales of resolution and in relation to GIS-based platforms for weather and land use.

Path of a suspect sample. An important contribution of the NPDN has been the education of first detectors in the proper procedure to follow when submitting samples to diagnostic labs (fig. 2). In California, a first detector may be a grower, crop consultant, pest control adviser, UC researcher, UC Cooperative Extension (UCCE) farm advisor, biologist within a county agriculture commissioner's office, UC-trained master gardener, employee of a city or county parks department or homeowner - really, any person who has been trained to recognize potential threats to plant health and understands the importance of plant biosecurity, and who knows how to collect and submit a sample securely.

Typically, the first detector retrieves a suspect sample from the field, packages it properly and delivers or mails it to the county agricultural commissioner or UCCE county office. There, it is identified or sent to the CDFA laboratory in Sacramento for further analysis and diagnosis by a specialist. Some samples that require specialized

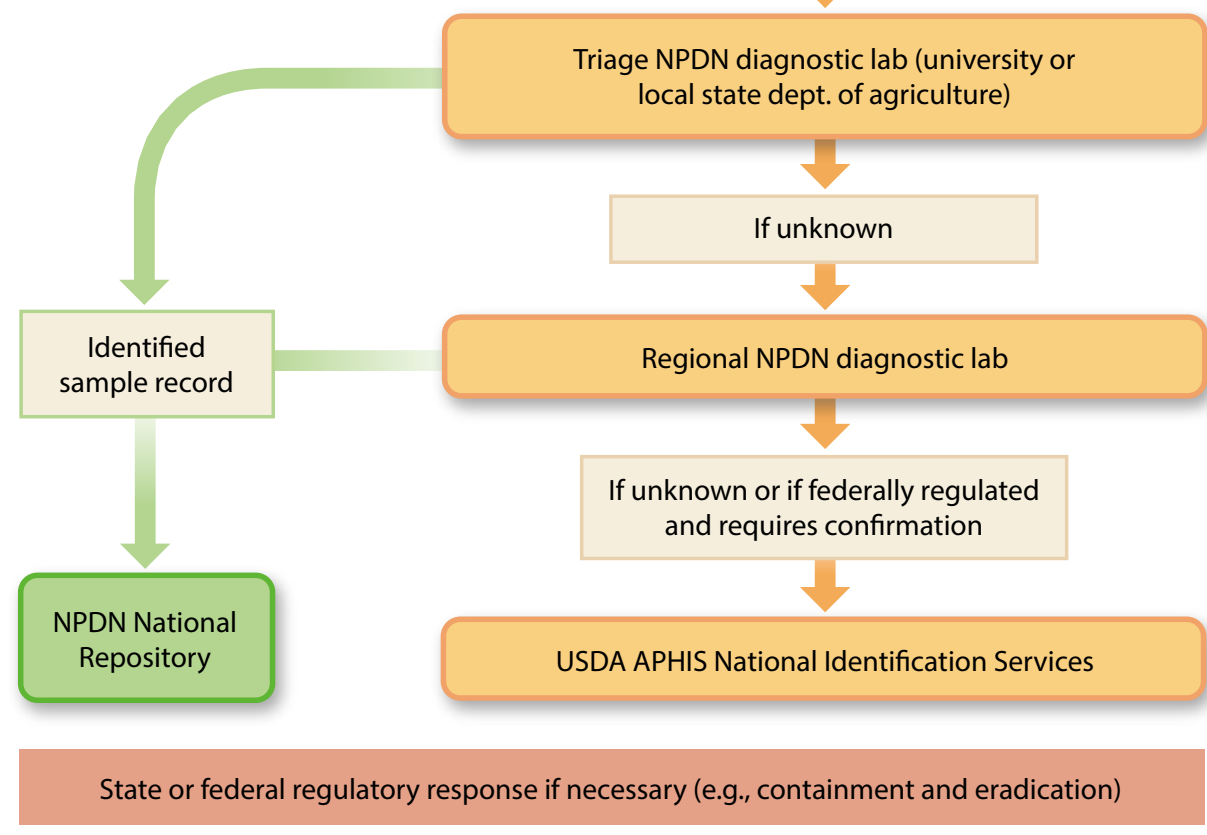

Fig. 2. Path of a field sample from first detector through the diagnostic process and ultimately to being archived as a record in the NPDN National Repository. diagnostics are often sent directly to UC laboratories that have the appropriate expertise. If the pest or pathogen is suspected to be new to California or to the county where it was found, a confirmatory diagnosis must be made by CDFA scientists, and may require further sampling. When a pest or pathogen is suspected to be new to the United States or to North America, samples are sent to the USDA Animal Plant Health Inspection Service (APHIS) National Identification Services, where specialists at federal, state or university laboratories with expert knowledge about the suspect agent are consulted for a confirmatory diagnosis.

How the NPDN has made a difference. Perhaps the most important contribution of the NPDN has been to foster an unprecedented level of coordination 
and communication among the nation's diagnostic laboratories. For example, in the event of a regional or national plant health emergency, instead of overwhelming one laboratory with samples, the distributed network structure provides a more flexible surge capacity, eliminating bottlenecks that could hamper the diagnostic and reporting process (see sidebar, page 121). In addition, through its regional networks and in partnership with USDA APHIS, the NPDN has made significant investments in laboratory infrastructure, equipment, supplies and distance diagnosis capabilities, and it has provided partial salary support and advanced training for scientific and technical staff.

Another important accomplishment of the NPDN is the development and delivery of training and education programs for first detectors and diagnosticians. The NPDN's national registry now includes more than 16,000 first detectors who can be alerted quickly to new outbreaks and who receive regular updates via national and regional e-newsletters with useful information about new pests and pathogens of regulatory concern. In California, currently boasting more

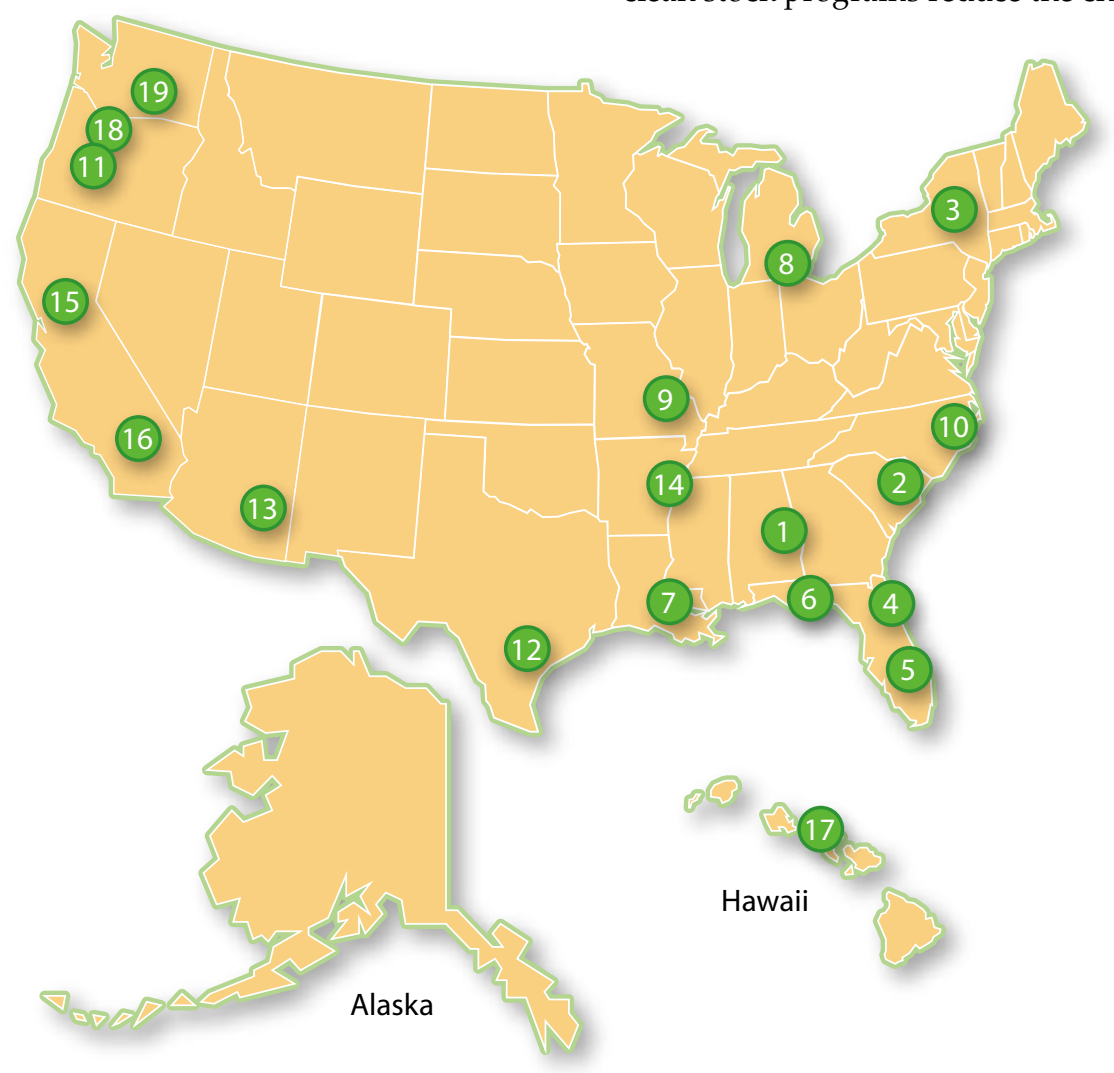

than 2,500 registered first detectors, the WPDN training coordinator and UCCE specialists and farm advisors and other UC Division of Agriculture and Natural Resources (ANR) personnel work together to conduct trainings and workshops. These are offered in conjunction with experts at universities, the CDFA and the USDA APHIS and USDA Agricultural Research Service (ARS) to ensure network-wide consistency and preparedness of diagnostic labs.

\section{The National Clean Plant Network}

Healthy planting stock is key to the cost-effective production of horticultural crops such as fruit trees, nut trees and grapevines. Healthy stock is easier to propagate, requires fewer chemical inputs and produces higher crop yields and better crop quality. The U.S. agricultural sector needs healthy planting stock to keep it internationally competitive and economically viable. The most efficient approach to producing healthy planting stock is through programs that screen valuable plant selections for viruses and other diseases that have the potential to be spread through contaminated plant stock. Quarantine services provided by clean stock programs reduce the chances of introduction of exotic pests that, once introduced, can be difficult and costly to control.

The original impetus for the organization of networks with a focus on clean stock came from the U.S. grape and fruit tree industries, which in 2005 began to explore the formation of a national group devoted to foundation materials that have been tested, treated and maintained as a healthy source of plant materials for growers to use. In 2008, these grape and fruit tree networks were developed by stakeholders, industry members, scientists and other interested parties. The new National Clean Plant Network (NCPN) was included in the 2008 and 2014 Farm Bills, with funding of $\$ 5$ million per year to provide reliable sources of propagative material that are free of graft-transmitted pathogens. Congress stipulated that funding go exclusively to existing clean plant centers that were already supported by their home institutions.

The NCPN is a voluntary association made up of specialty crop networks that promote the use of pathogen-tested, healthy plant material for U.S. growers of grapes, fruit trees, hops, berries and citrus. Its formal mission is to "provide high quality asexually propagated plant material free of targeted plant pathogens and pests that cause economic loss to

1. Auburn University, Auburn, Alabama

2. Clemson University, South Carolina

3. Cornell University, Geneva, New York

4. Florida Department of Agriculture and Consumer Service, Gainesville

5. Florida Department of Agriculture and Consumer Service, Winter Haven

6. Florida A\&M University, Tallahassee

7. Louisiana State University, Baton Rouge

8. Michigan State University, East Lansing

9. Missouri State University, Mountain Grove

10. North Carolina State University, Raleigh

11. Oregon State University, Corvallis

12. Texas A\&M University (TAMUK), Kingsville

13. University of Arizona, Yuma

14. University of Arkansas, Fayetteville

15. University of California, Davis

16. University of California Riverside, in collaboration with USDA ARS National Clonal Germplasm Repository for Citrus and Dates

17. University of Hawaii, Honolulu

18. USDA ARS, Corvallis, Oregon

19. Washington State University-IAREC, Prosser

Fig. 3. The 19 regional centers of the National Clean Plant Network (NCPN). 
protect the environment and ensure the global competitiveness of specialty crop producers." By agreement, it operates under the auspices of three federal agencies - USDA APHIS, ARS and NIFA - which cooperatively support its research, quarantine and outreach activities.

USDA funding supports existing clean plant centers that have the expertise, facilities and appropriate climates to efficiently produce, maintain and distribute healthy planting stock for those crops. Advisory committees that include industry representatives and researchers from throughout the country make up an essential part of the equation for communicating priorities to the NCPN.

NCPN centers. As of this writing, the NCPN network includes 19 clean plant centers (fig. 3). Each of the five current crop programs has one program that serves as its administrative lead. A national website (nationalcleanplant network.org) maintained by the staff of Foundation Plant Services (FPS) at UC Davis has links to a website for each of the NCPN crops maintained by the administrative lead center. UC Davis is administrative home for the grape network. The NCPN berries group - the Berry Crops Testing, Therapy and Diagnostics Development Program - is headquartered at the USDA Horticultural Crops Research Unit, USDA ARS, in Corvallis, Oregon. The citrus network home is with the Citrus Clonal Protection Program (CCPP) at UC Riverside (see below). Both the fruit tree network and the hops network are housed at Clean Plant Center Northwest, Washington State UniversityIAREC, in Prosser, Washington.

\section{Citrus Clonal Protection Program}

The CCPP has its roots in the 1930s, when Professor Howard Fawcett of the UC Citrus Experiment Station in Riverside discovered the viral nature of the graft-transmissible disease citrus psorosis - the discovery that triggered the establishment of the Psorosis Free Program. Following a request from the citrus industry, UC established what is now the CCPP in 1956, initially calling it the Citrus Variety Improvement Program. Today the CCPP stands as a cooperative program of UC Riverside's Department of Plant Pathology and Microbiology, CDFA, USDA APHIS and the NCPN, as well as the state's citrus industry as represented

\section{A broad lab network means greater flexibility and better response}

$T^{T}$ he "surge capacity" of the National Plant Diagnostic Network (NPDN) was instrumental in providing support for several investigations of Phytophthora ramorum, the cause of sudden oak death in coastal forests and ramorum blight of ornamentals (Rizzo et al. 2005). In 2004, P. ramorum was unexpectedly detected in several Southern California production and wholesale nurseries that had already shipped 2.3 million potentially infected plants to retail nurseries and other wholesale nurseries in 49 states and the District of Columbia. This triggered a national regulatory response to determine where plants had been shipped and then, once found, to test the plants for P. ramorum.

Over the next year, federal and NPDN labs processed more than 100,000 samples. Because of the NPDN laboratories' advanced coordination and training, they were able to rapidly implement the standardized APHIS diagnostic protocol with little advance notice. One critical element of this protocol is a molecular diagnostic based on the PCR assay, which at the time was newly developed by APHIS and UC scientists. In addition, the NPDN provided support for the purchase of PCR machines and supplies and reagents that enabled many network labs to participate. In total, 171 nurseries in 20 states tested positive for P. ramorum, triggering implementation of containment and eradication measures at those sites.

Prior to establishment of the network, it could take 6 weeks or more for samples to go through the system, and nursery plants were quarantined until diagnosis could be completed. With the NPDN labs and the new diagnostic assay, turnaround times from field collection to diagnosis were reduced to as few as 4 days, enabling many nurseries around the country to quickly resume operations once they had been cleared as free from $P$. ramorum. CA

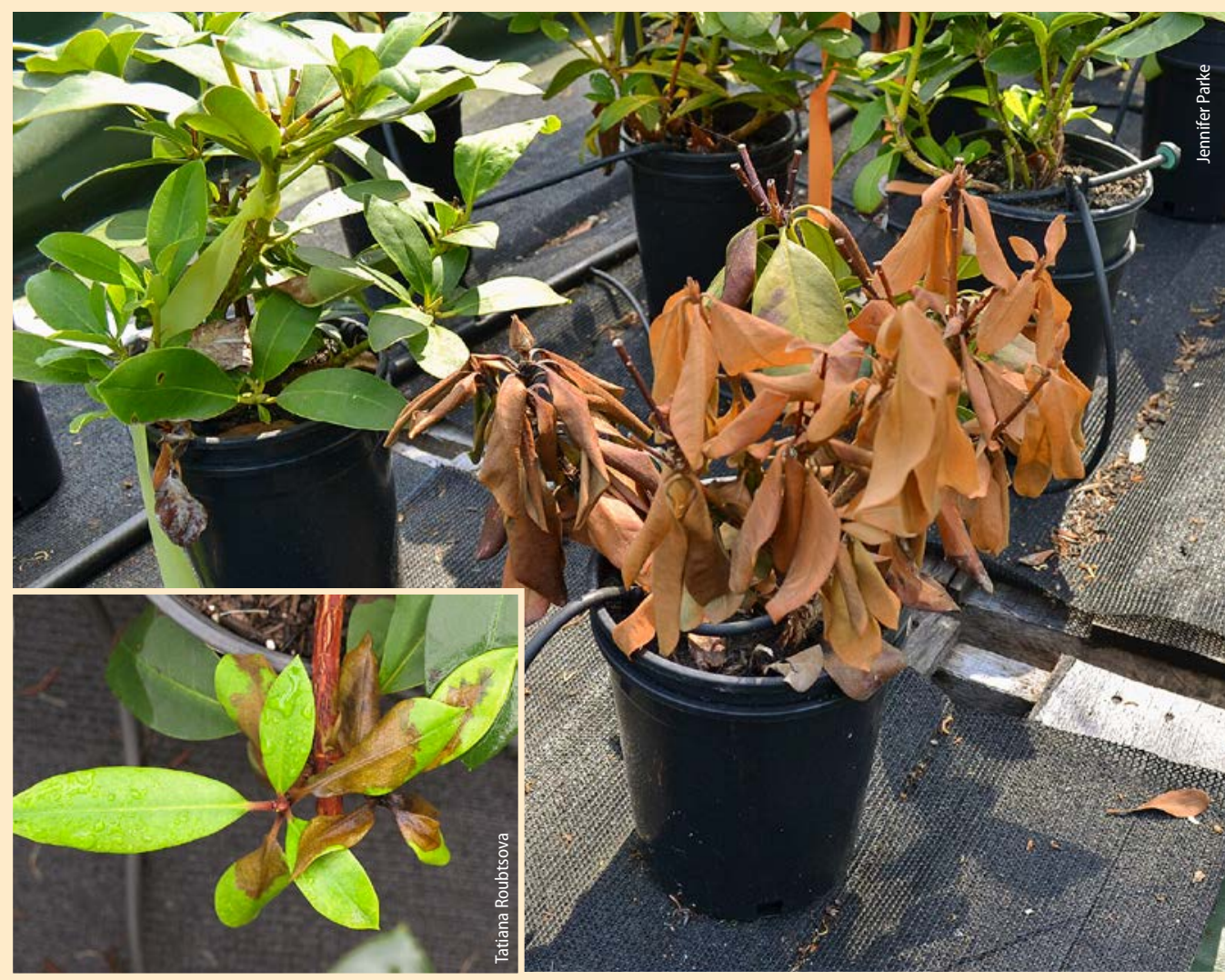

Rhododendron plants declining from ramorum blight caused by Phytophthora ramorum in a commercial nursery. Inset, leaf symptoms of ramorum blight on Rhododendron. 
by the California Citrus Nursery Board (CCNB) and the Citrus Research Board (CRB).

The CCPP operates at three locations: the Rubidoux Quarantine Facility in downtown Riverside, the Citrus Diagnostic Laboratory on the UC
Riverside campus and the Foundation and Evaluation Blocks at the UC Lindcove Research and Extension Center, in Exeter, California. The CCPP is supported by the CRB and CCNB (industry organizations founded in 1968 and 2005, respectively, in response to the California State Handler
Marketing Orders), while UC Riverside offers infrastructure support and scientific expertise. A committee of industry members (growers and nursery people) supports the CCPP activities.

The CCPP is the basic element of a long-term, multilevel program whose

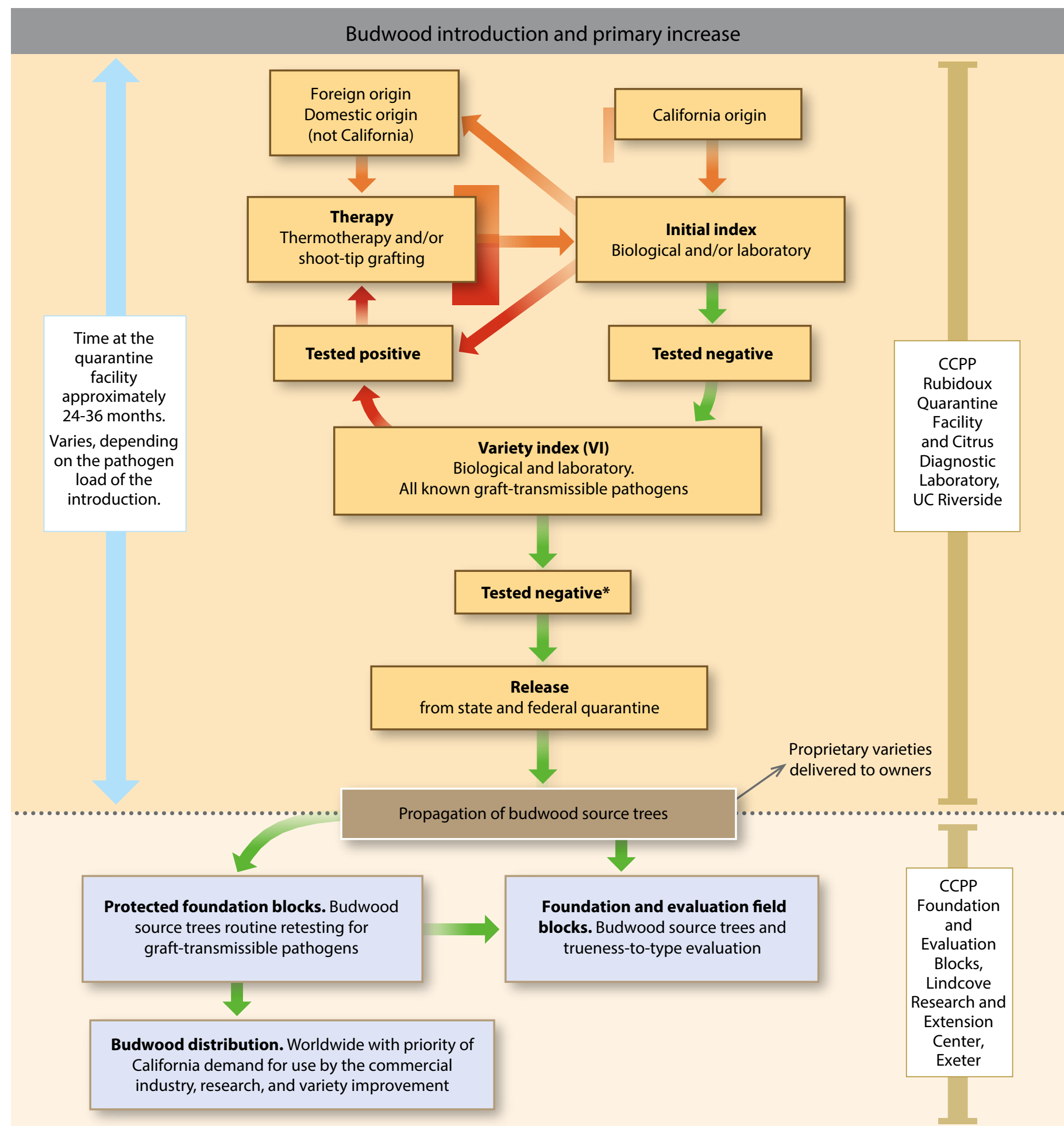

Fig. 4. Flow chart for citrus budwood introduction, propagation of source trees and distribution conducted by the Citrus Clonal Protection Program (CCPP). * To fulfill movement requirements between quarantine zones, all materials must undergo therapy regardless of the pre-index results. 
objectives include avoiding or restricting the spread of bud- and graft-transmitted pathogens of citrus in support of a profitable, competitive and sustainable citrus industry. As such, the CСPP provides a safe mechanism for the introduction of citrus varieties into California from any area around the world. The process for varietal introduction includes disease diagnosis and pathogen elimination followed by maintenance, pathogen retesting and distribution of true-to-type citrus propagative material (fig. 4).

The CCPP program of importation, production and distribution of pathogentested propagative materials is based on a comprehensive indexing (testing) program to detect graft-transmissible diseases and pathogens that may arrive in imported budlines. Graft-transmissible diseases may be caused by viruses, viroids or other pathogens (e.g., bacteria, phytoplasmas) and are vegetatively transmitted with an infected budline. Grafttransmissible diseases can seriously harm fruit quality, production and tree health and longevity. In addition, diseases from infected field propagation may spread to neighboring orchards via insects or contaminated farm equipment (Timmer et al. 2000; Wallace 1978).

Disease diagnosis and pathogen detection take place in the insect-proof greenhouse and the Delfino Plant Laboratory at the Rubidoux Quarantine Facility as well as in the Citrus Diagnostic Laboratory at UC Riverside. Detection of graft-transmissible citrus diseases is based on a comprehensive indexing scheme that involves biological and laboratory diagnostics.

For biological indexing, technicians graft tissue from the imported budline onto citrus indicator plants, with a specific citrus indicator for each specific disease. Indicator varieties have been selected for their sensitivity to diseases and their ability to express symptoms. For each index, technicians maintain adequate positive control plants under the same environmental conditions as the test indicators. The controls serve dual purposes: They provide a comparison for the test plant and also demonstrate that environmental conditions in the greenhouse are optimal for plant growth and symptom expression (Childs 1978; Roistacher 1991; Vidalakis et al. 2004).

Citrus propagative material (i.e., budwood) distributed to homeowners, hobbyists, citrus growers and nurseries draws from tree sources of the CCPP foundation block. All CCPP- and nursery-owned citrus budwood tree sources must be established and propagated from citrus material that has been through the CCPP introductory, therapy and diagnostic protocols, regularly and routinely tested for several citrus pathogens, and registered as a budwood source with the CDFA. In May 2010, CDFA filed regulations for a mandatory Citrus Nursery Stock Pest Cleanliness Program as an emergency action. Under this new mandatory program, more than 8,000 registered budwood source trees were tested for several citrus pathogens in the first 2 years. The CCPP and UC Riverside researchers have been instrumental in the development of a
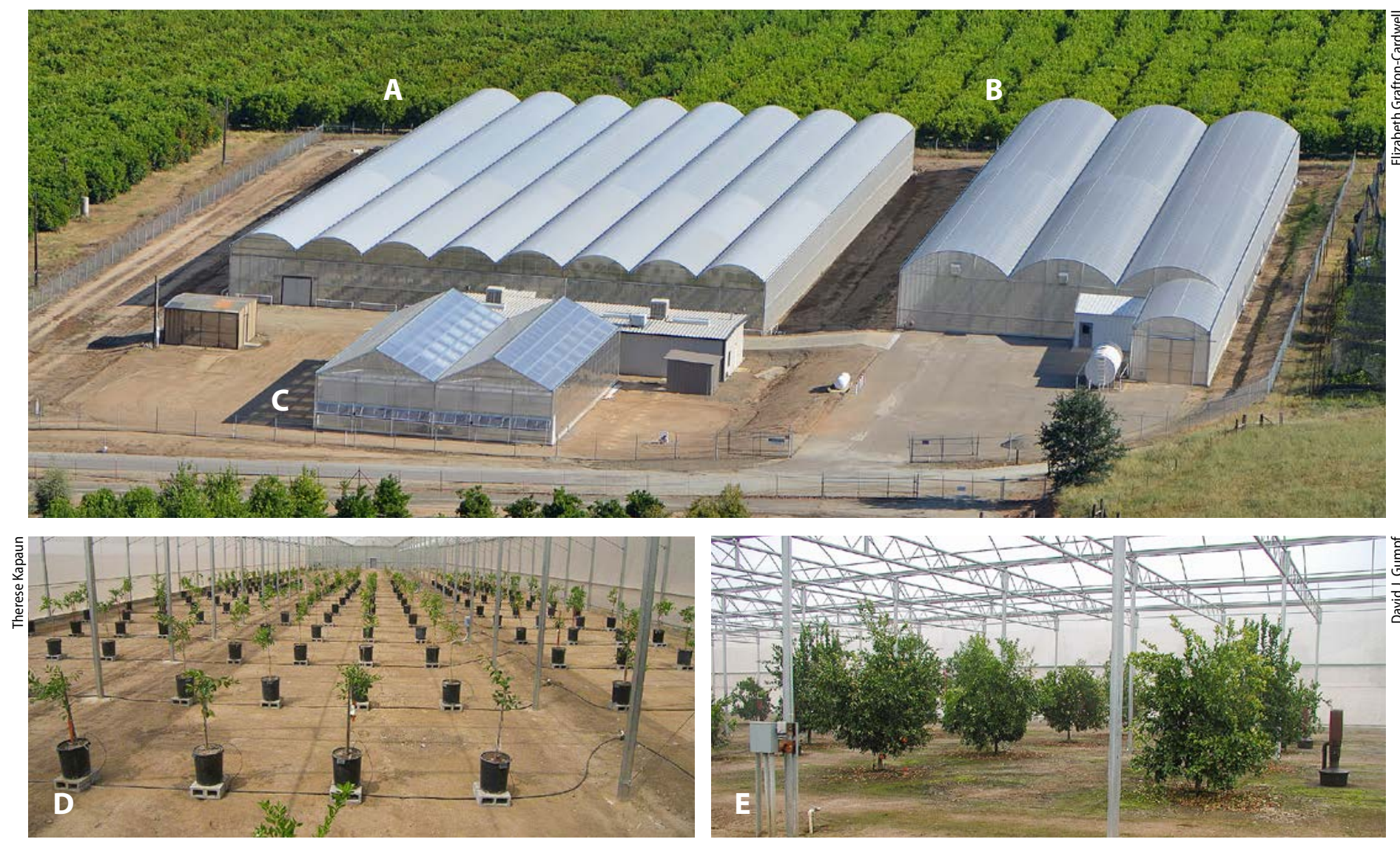

Fig. 5. Panoramic view of the Citrus Clonal Protection Program Protected Foundation Block in the UC Lindcove Research and Extension Center in Tulare County. (A) The first screenhouse (40,000 sq ft) was constructed between 1998 and 1999, (B) the second screenhouse ( $30,000 \mathrm{sq} \mathrm{ft}$ ) was completed in 2010 and $(C)$ the positive pressure greenhouse $(5,700 \mathrm{sq} f t)$ was completed in 2011. The interior of the screenhouses with both (D) container and (E) in-ground budwood source trees. 
high-throughput nucleic acid extraction and purification procedure optimized for citrus budwood tissues as well as molecular diagnostic methods for detection of citrus pathogens. These efforts have enabled the successful implementation of the new $\S 3701$ CDFA Citrus Nursery Stock Pest Cleanliness Program (Vidalakis and Wang 2013; CDFA permits QC 1354 and QC 1388, www.cdfa.ca.gov/ plant/pe/nsc/nursery/citrus.html).

Since 2009, CCPP has supplied 154,000 buds from 301 different citrus varieties. A citrus nursery can produce as many as 300 trees within a year to 18 months from each CCPP bud. That means that an estimated 231 million citrus trees have been produced from pathogen-tested CCPP material in the past 5 years alone. If a single pathogen had been present in any of the buds used for this tree propagation, it would have been transmitted to millions of trees, with unknown horticultural, production and economic effects.

Diseases can sometimes become so important in citrus production that it may be necessary, for example, to change from a long-used rootstock to one that is more tolerant or resistant to a disease agent. Such was the case when citrus tristeza disease became a limiting factor for citrus production in California. Millions of trees growing on sour orange rootstock, which was susceptible to tristeza quick decline, had to be replaced with trees grown on tristeza-tolerant rootstocks of trifoliate and trifoliate hybrids. The availability of pathogen-tested tristeza-tolerant rootstocks and scions (e.g., mandarins) from the CCPP was critical to the industry's transition and subsequent economic success (Barnier et al. 2010; Calavan et al. 1978). The availability of a wide selection of citrus species, varieties and selections for evaluation and experimental use is essential to our ability to address new and emerging problems such as citrus greening.

Another important factor for the health and sustainability of the commercial citrus industry is maintenance of our capacity to import new varieties having different or improved fruit qualities or different maturity dates and organoleptic characters to satisfy ever-changing consumer demands. A capacity to import and maintain new pathogen-free citrus germplasm is imperative to keeping risk to the industry at a minimum and enabling research to move forward. The only way we can meet these goals is through a program like the CCPP that works collaboratively with state and federal regulators, the citrus industry and UC to release pathogen-tested citrus varieties.

\section{Partnerships for plant health}

The three programs described here demonstrate how investments in diagnostics, germplasm screening and development, and related training and education are helping to safeguard agriculture and plant resources at statewide, regional and national levels. These programs provide the agricultural industry with healthy planting stock as well as highly coordinated systems to deal efficiently with disease and pest outbreaks. Their success is due to the commitment of resources by the USDA, state agencies, industry and LGUs.

Especially critical to the success of these programs in California are the contributions of ANR and CDFA scientists and support staff. Yet recent limitations in state and federal funding for agricultural science have put the continuation of these programs in serious jeopardy. Reduced funding will weaken interagency collaboration and sharing of expertise, limit training and education programs, reduce

\section{References}

Barnier JB, Grafton-Cardwell E, Polek M. 2010. Citrus tristeza virus (CTV): Then and now. Citrograph 6:16-23. Calavan CE, Mather SM, McEachern EH. 1978. Registration, certification, and indexing of citrus trees. In: Reuther W, Calavan EC, Carman GE (eds.). The Citrus Industry (Vol. IV): Crop Protection. Berkeley, CA: University of California, Division of Agricultural Sciences. p 185-222. [CDFA] California Department of Food and Agriculture. 2013. California Agricultural Statistics Review 2012 2013. California Department of Food and Agriculture, Sacramento, CA. 131 p.

Childs JFL (ed.). 1978. Indexing Procedures for 15 Virus Diseases of Citrus Trees. Agricultural Research ServiceUnited States Department of Agriculture, Washington, DC

Crooks JA. 2005. Lag times and exotic species: The ecology and management of biological invasions in slowmotion. Ecoscience 12(3):316-29.

Liebhold AM, Brockerhoff EG, Garrett LJ, et al. 2012. Live plant imports: The major pathway for forest insect and pathogen invasions of the US. Front Ecol Environ 10(3):135-43

Palm ME, Rossman AY. 2003. Invasion pathways of terrestrial plant-inhabiting fungi. In: Ruiz JM, Carleton JT (eds.). Invasive Species: Vectors and Management Strategies. Washington, DC: Island Press. p 31-43.

Pimentel D, Zuniga R, Morrison D. 2005. Update on the environmental and economic costs associated with alien-invasive species in the United States. Ecol Econ 52(3):273-88. the speed with which samples can be processed and put our general preparedness to address plant health emergencies at risk. Increases in agricultural trade and plant importation, together with the importance of sustainable production systems for food and fiber, mean that the demand for integrated programs to provide accurate, rapid diagnoses in support of plant health has never been greater. CA

R.M. Bostock is Plant Pathologist, California Agricultural Experiment Station, and Professor and Director, Western Regional Center of the NPDN, Department of Plant Pathology, UC Davis; C. Thomas is Associate Director, Western Regional Center of the NPDN, Department of Plant Pathology, UC Davis; R.W. Hoenisch is Training and Education Coordinator, Western Regional Center of the NPDN, Department of Plant Pathology, UC Davis; D.A. Golino is Director, Foundation Plant Services, and UC Cooperative Extension Specialist, Department of Plant Pathology, UC Davis; and G. Vidalakis is Director, Citrus Clonal Protection Program, Assistant Plant Pathologist and Assistant UC Cooperative Extension Specialist, Department of Plant Pathology, UC Riverside.

Rizzo DM, Garbelotto M, Hansen EA. 2005. Phytophthora ramorum: Integrative research and management of an emerging pathogen in California and Oregon forests. Annu Rev Phytopathol 43:309-35.

Roistacher CN. 1991. Graft-transmissible diseases of citrus. Handbook for detection and diagnosis. Rome: Food and Agriculture Organization of the United Nations (FAO). www.fao.org/docrep/t0601e/t0601e00.HTM Rossman A. 2009. The impact of invasive fungi on agricultural ecosystems in the United States. Biol Invasions 11(1):97-107.

Stack JP, Bostock RM, Hammerschmidt R, et al. 2014. The National Plant Diagnostic Network: Partnering to protect plant systems. Plant Dis 98:708-15.

Stack J, Cardwell K, Hammerschmidt R, et al. 2006. The National Plant Diagnostic Network. Plant Dis 90(2):128-136.

Timmer LW, Garnsey SM, Graham JH. 2000. Graft-transmissible, systemic diseases. In: Compendium of Citrus Diseases. St. Paul, Minnesota: APS Press. p 51-69.

Vidalakis G, Garnsey SM, Bash JA, et al. 2004. Efficacy of bioindexing for graft-transmissible citrus pathogens in mixed infections. Plant Dis 88(12):1328-34.

Vidalakis G, Wang J. 2013. Molecular method for universal detection of citrus viroids. US Patent No. $20,130,115,591$

Wallace JM. 1978. Virus and viruslike diseases. In Reuther W, Calavan EC, Carman GE (eds.). The Citrus Industry (Vol. IV): Crop Protection. Berkeley, CA: University of California, Division of Agricultural Sciences. p 69-72. 